\title{
THE LEGISLATURE STRIKES BACK: THE EFFECT OF ONTARIO'S BILL 152 ON THE BENEFICIARIES OF THE STATUTORY DUTY OF CARE IN THE PEOPLES DECISION
}

\author{
DARCY L. MACPHERSON*
}

In this article, the author critically analyzes the Supreme Court of Canada's decision in Peoples Department Stores Inc. v. Wise. This decision interpreted s. 122(1) of the Canada Business Corporations Act in a way so as to declare that it was "obvious" that the duty of care placed on directors and officers is owed to a broad range of beneficiaries, including creditors. The author argues that the decision, while defensible, was neither "obvious" nor was it appropriate. The amendments to the Ontario Business Corporations Act may come closer to the intentions of Parliament in passing the Canada Business Corporations Act. Furthermore, the rules of statutory interpretation are employed to demonstrate that the broadened duty of care found by the Supreme Court may actually cause directors and officers to be more self-interested, rather than putting the interests of the corporation ahead of their own. Such a change in approach may lead to statutory absurdity or a violation of the presumption against tautology. Therefore, a narrower duty of care, owed only to the corporation, as enacted by the Ontario legislature, should be recognized.
Dans cet article, l'auteur analyse de manière critique la décision de la Cour suprême du Canada Magasins à rayons Peoples inc. c. Wise. Cette décision interprète l'article 122 (1) de la Loi canadienne sur les sociétés par actions de manière à déclarer qu'il était «évident» que les administrateurs et dirigeants ont un devoir de diligence à l'égard de nombreux bénéficiaires, dont les créanciers. $L$ 'auteur fait valoir que la décision, quoique défendable, n'était ni «évidente» ni indiquée. Les amendements à la Loi sur les sociétés par actions de l'Ontario pourraient mieux respecter l'esprit du Parlement en adoptant la Loi canadienne sur les sociétés par actions. De plus, les règles d'interprétation des lois servent à démontrer que la définition élargie de devoir de diligence de la Cour suprême peut en fait amener les administrateurs et les dirigeants à être plus intéressés au lieu de mettre les intérêts de la société devant leurs propres intérêts. Un tel changement de démarche pourrait mener à une absurdité des lois ou une violation de la présomption de tautologie. Par conséquent, il faudrait reconnaître une définition plus étroite du devoir de diligence, visant uniquement la société telle qu'adoptée par le gouvernement de l'Ontario.

\section{TABLE OF CONTENTS}

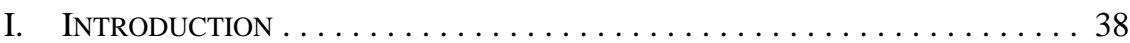

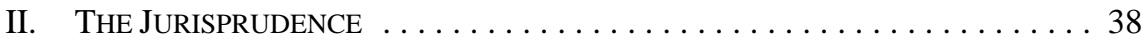

A. PEOPLES DEPARTMENT STORES INC.

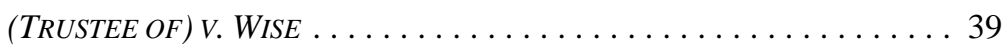

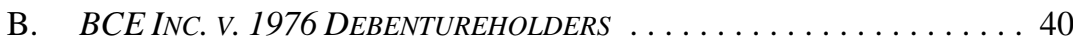

III. ThE StATUtORY PROVISIONS $\ldots \ldots \ldots \ldots \ldots \ldots \ldots \ldots \ldots \ldots \ldots \ldots$

IV. ANALYSIS ........................... 43

A. Is IT Obvious? $\ldots \ldots \ldots \ldots \ldots \ldots \ldots \ldots \ldots \ldots \ldots \ldots \ldots \ldots \ldots \ldots$

Associate Professor, Faculty of Law, University of Manitoba. Associate, Marcel A. Desautels Centre for Private Enterprise and the Law, Faculty of Law, University of Manitoba. Generous financial support for this project was received from the Legal Research Institute, University of Manitoba. My discussions with many people have helped to refine - and occasionally, to redefine - my thinking on the issues discussed herein. Professors Evaristus Oshionebo and John Pozios have been especially prominent in this regard. The research assistance of both Ryan Johnson and James Wood is also gratefully acknowledged. Thanks are also owed to the anonymous peer reviewers, whose considered comments and suggestions for changes were immensely helpful in improving the final product. Any errors, of course, remain the sole responsibility of the author. 
B. Reliance on the Civil Code of QUÉBEC . . . . . . . . . . 46

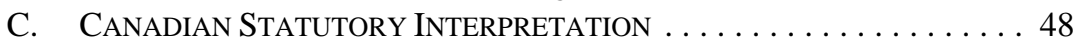

D. DOES THIS MEAN THAT DiRECTORS

CAN Never Be Liable? . . . . . . . . . . . . . . . . . . 68

V. WHAT IS NEXT? . . . . . . . . . . . . . . . . . . 71

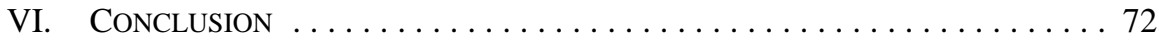

\section{INTRODUCTION}

In 2004, the Supreme Court of Canada released its decision in Peoples. ${ }^{1}$ Amongst other things, the Court held that the statutory duty of care was owed not only to the corporation, but also to many others, including creditors. ${ }^{2}$ This is one of the more controversial elements of the decision, ${ }^{3}$ yet the Court claimed that this result was "obvious" from the wording of the statute.

As of 1 August 2007, ${ }^{4}$ by amending its Business Corporations $A c t^{5}$ the Ontario legislature has made it plain that, among other things, for companies incorporated in its jurisdiction the statutory duty of care is not owed to any person other than the corporation.

The point of this article is to offer some perspective on this element of the Ontario legislation through the lens of Peoples as the corporate bar anxiously awaits the next decision of the Supreme Court on this subject. The basic argument in this article is that based on the norms of Canadian statutory interpretation, the revised Ontario legislation comes closer to the intention of Parliament in passing s. 122(1) of the Canada Business Corporations Act ${ }^{6}$ than did the judgment in Peoples.

\section{THE JURISPRUDENCE}

As the title suggests, the primary focus of this article will be on the Peoples judgment. However, there is some subsequent jurisprudence from the Supreme Court that could possibly affect the analysis offered below. Therefore, a review of $B C E^{7}$ will also be provided.

Peoples Department Stores Inc. (Trustee of) v. Wise, 2004 SCC 68, [2004] 3 S.C.R. 461 [Peoples].

Ibid. at para. 1.

See Wayne D. Gray, “A Solicitor’s Perspective on Peoples v. Wise” (2005) 41 Can. Bus. L.J. 184 at 19192, where the author argues that "it would be better" if the court had not extended the beneficiaries a statutory duty of care. 


\section{A. Peoples Department Stores Inc. (Trustee Of) V. Wise}

\section{THE FACTS}

The basic facts of the Peoples decision (insofar as they are relevant to the issues addressed in this article ${ }^{8}$ ) were as follows: the individual defendants were three brothers who were directors of Wise Stores Inc. ${ }^{9}$ Wise Stores Inc. wanted to acquire its competitor, Peoples. Peoples was owned by Marks \& Spencer Canada Inc. (M \& S). ${ }^{10} \mathrm{M} \& \mathrm{~S}$ was willing to go forward with the divestiture as long as the assets were acquired in such a way that they were "ring-fenced," to ensure payment of the purchase price. Therefore, Wise Stores was not allowed to amalgamate with Peoples following the acquisition until full payment of the purchase price. ${ }^{11}$ Peoples therefore became a subsidiary of Wise Stores Inc., with the brothers serving as directors of Peoples. ${ }^{12}$

The goal was to have Peoples and Wise Stores function as a coherent group, but this was not successful. ${ }^{13}$ Consequently, the brothers consulted with Peoples' vice-president of administration and finance to to develop a plan for streamlining operations. The vicepresident (Clément) recommended an inventory policy whereby Wise Stores would make international inventory purchases, while Peoples would make North American purchases; each would then bill the other for inventory used by the other. ${ }^{14}$ Since this was not an even trade, it resulted in Wise Stores owing large sums to Peoples. ${ }^{15}$ When the plan was proposed, the $\mathrm{M} \& \mathrm{~S}$ representative on the board did not object. ${ }^{16}$ However, once a \$14 million receivable was owing from Wise to Peoples as a result of the policy, M \& S demanded changes and the major bank for the group threatened to withdraw, and did so shortly thereafter. ${ }^{17}$ After poor financial results in the next quarter, both Wise Stores and Peoples were petitioned into bankruptcy. ${ }^{18}$ In the petition, the trustee in bankruptcy claimed that the Wise brothers had breached their statutory fiduciary duty and their duty of care. ${ }^{19}$

\section{THE HOLdings OF THE SUPREME COURT}

The Supreme Court of Canada held that the statutory fiduciary duty is owed only to the corporation. ${ }^{20}$ The duty of care, however, should be construed much more broadly and is

A complete statement of the facts can be found in Peoples, supra note 1 at paras. 4-28. See also "Common Statement of Facts" (2005) 41 Can. Bus. L.J. 168 at 168-74. For an interesting analysis of some of the facts on which the trial judge relied but the Supreme Court did not, see Warren Grover, "The Tangled Web of the Wise Case” (2005) 41 Can. Bus. L.J. 200.

Peoples, ibid. at para. 4.

Ibid. at para. 5.

Ibid. at para. 11.

Ibid. at para. 12.

Ibid. at para. 13.

Ibid. at para. 17.

Ibid. at para. 18 .

Ibid. at para. 19.

Ibid. at paras. 20-22.

Ibid. at para. 23.

Ibid. at para. 25.

Ibid. at para. 43. 
owed to a much wider class of beneficiaries, including creditors. ${ }^{21}$ Furthermore, the Court, taking a very different stance from previous jurisprudence on the issue, ${ }^{22}$ held that the statutory duty of care is purely objective in nature, without any explicitly subjective elements. ${ }^{23}$ The duty of care is to be judged on a standard of prudence and reasonable information. ${ }^{24}$ The one exception to this is the business judgment rule. ${ }^{25}$ For the purpose of this article, I will leave aside the "safe harbour" provisions that were also altered as a result of the Ontario legislation. ${ }^{26}$

\section{B. BCE INC. V. 1976 DEBENTUREHOLDERS}

\section{THE FACTS}

In this case, BCE Inc. (BCE) was proposing a leveraged buyout of its assets. ${ }^{27}$ This was largely due to having been put "in play" by a particular filing with the United States Securities and Exchange Commission by one of its largest shareholders. ${ }^{28}$ There was an auction process ${ }^{29}$ and, in response to debenture holder concerns, assurances were given that BCE would not accept bids that did not honour the terms of the trust indentures under which the debentures were issued. ${ }^{30}$ When the bid of the ultimate winner in the auction process the transaction failed to close for reasons unrelated to the analysis offered here - was first submitted, the bid would have triggered voting rights of the debenture holders. The winning bidder was told that this fact would make the bid less competitive than the other two received. The bid was consequently revised, so as (among other things) not to trigger debenture holder voting rights. ${ }^{31}$

The board was very forthright in noting that it was interested in the effect of the transaction on BCE and its shareholders and did not seek a fairness opinion with respect to the position of the debenture holders. ${ }^{32}$ The opposition of the debenture holders to the transaction was largely based on the fact that, while shareholders were receiving a premium, the debentures would lose 20 percent of their value and would drop below investment grade. ${ }^{33}$

Ibid. at para. 57

Soper v. Canada, [1998] 1 F.C. 124 (C.A.) [Soper].

Peoples, supra note 1 at para. 63.

Ibid. at paras. 66-67.

Ibid. at para. 64 .

This is not meant to suggest that the change to the safe harbour provisions is insignificant or unimportant. In fact, quite the contrary is true. My reason for not dealing with the safe harbour provisions is that I view them as important enough to warrant separate attention, rather than trying to fold them into an analysis of the class of beneficiaries to whom the duty of care is (or should be) owed. Therefore, a fulsome discussion of the safe harbour provisions will have to wait for another day. $B C E$, supra note 7 at para. 4 .

Ibid. at para. 13.

Ibid.

Ibid. at paras. 15-16.

Ibid. at para. 17.

Ibid. at para. 18.

Ibid. at paras. 20-21. 
The debenture holders argued that the transaction constituted oppression on the part of the directors ${ }^{34}$ and that the transaction was not "fair and reasonable" and, therefore, could not be approved by the Court pursuant to s. 192 of the $C B C A .^{35}$ The debenture holders also alleged violations of the trust indentures when the debentures were issued, but this matter was not raised before the Supreme Court. ${ }^{36}$

\section{THE HOLDINGS OF THE SUPREME COURT}

The Supreme Court of Canada held that the duty of care was not directly relevant to the issues in the case before the Court. ${ }^{37}$ However, in the author's view, there is likely some degree of overlap between the "reasonableness of the transaction" for the purposes of s. 192 of the CBCA and the duty of care, since they are both based on the concept of reasonableness. Also, the Court made it clear that the duty of care is a potential remedy for those aggrieved by corporate actions, ${ }^{38}$ however, it does not create an independent foundation for claims. ${ }^{39}$ In addition to the fiduciary duty (owed only to the corporation) and the duty of care (owed to the corporation and others, including creditors), there is also the oppression remedy pursuant to s. 241 of the $C B C A$. The fourth remedial provision is s. 192, which was directly relevant to the resolution of the issues before the Court.

\section{The Statutory Provisions}

In order to discuss the effect of the Ontario legislation, it is necessary to set out both the $C B C A$ (the legislation at issue in Peoples itself), and the equivalent section of the $O B C A$, as amended. The CBCA provision is reproduced below:

Every director and officer of a corporation in exercising their powers and discharging their duties shall

(a) act honestly and in good faith with a view to the best interests of the corporation; and

(b) exercise the care, diligence and skill that a reasonably prudent person would exercise in comparable circumstances. $^{40}$

On the other hand, the amended Ontario provision reads as follows:

Every director and officer of a corporation in exercising his or her powers and discharging his or her duties to the corporation shall,

(a) act honestly and in good faith with a view to the best interests of the corporation; and

Ibid. at para. 22.

Ibid.

Ibid.

Ibid. at para. 36 .

Ibid. at para. 44.

Ibid.

CBCA, supra note 6, s. 122(1). 
(b) exercise the care, diligence and skill that a reasonably prudent person would exercise in comparable circumstances. ${ }^{41}$

Thus, the only difference between the CBCA, as discussed in Peoples, and the amended $O B C A$ is the addition of the words "to the corporation."

Certain other provisions of the CBCA are also relevant to the analysis in this article. These read as follows:

119 (1) Directors of a corporation are jointly and severally, or solidarily, liable to employees of the corporation for all debts not exceeding six months wages payable to each such employee for services performed for the corporation while they are such directors respectively.

(2) A director is not liable under subsection (1) unless

(a) the corporation has been sued for the debt within six months after it has become due and execution has been returned unsatisfied in whole or in part;

(b) the corporation has commenced liquidation and dissolution proceedings or has been dissolved and a claim for the debt has been proved within six months after the earlier of the date of commencement of the liquidation and dissolution proceedings and the date of dissolution; or

(c) the corporation has made an assignment or a bankruptcy order has been made against it under the Bankruptcy and Insolvency Act and a claim for the debt has been proved within six months after the date of the assignment or bankruptcy order.

122 (3) Subject to subsection 146(5), no provision in a contract, the articles, the by-laws or a resolution relieves a director or officer from the duty to act in accordance with this Act or the regulations or relieves them from liability for a breach thereof.

123 (4) A director is not liable under section 118 or 119, and has complied with his or her duties under subsection 122(2), if the director exercised the care, diligence and skill that a reasonably prudent person would have exercised in comparable circumstances, including reliance in good faith on

(a) financial statements of the corporation represented to the director by an officer of the corporation or in a written report of the auditor of the corporation fairly to reflect the financial condition of the corporation; or

(b) a report of a person whose profession lends credibility to a statement made by the professional person. ${ }^{42}$ 


\section{ANALYsis}

Before I begin my analysis, three points should be emphasized. First, the actual result in the Peoples case, that directors should not be liable to the representative of the unsecured creditors, is not really at the core of the argument made herein. The primary concern is what the law should be. The application of the law to the facts of Peoples is, for the purpose of this article, of less importance. Thus, very little attention will be focused on whether or not the facts of Peoples justify the substantive result offered by the Court.

Second, given that the $O B C A$ alteration was merely one small part of a rather large piece of omnibus legislation, relatively few conclusions can be drawn from the Hansard discussion of the bill. A review of the explanatory notes to the bill shows that, with respect to the $O B C A$, the goal was to "modernize" the language of the $O B C A .{ }^{43}$ However, in my view, there is no doubt that the legislature intended to reverse one of the major holdings of the Peoples judgment. In fact, the explanatory notes do not draw a distinction between fiduciary duty and the duty of care at all. The relevant portion reads:

The amendments to sections 134, 135 and 136 of the Act clarify that directors and officers owe their fiduciary obligations exclusively to the corporation. The amendments provide a reasonable diligence defence for directors and expand and clarify the good faith reliance defence in respect of interim and other financial reports and reports and advice of subordinates. ${ }^{44}$

Since the change to the language of s. 134 is so specific and this was the first amendment to the $O B C A$ following the release of the decision in Peoples, it leads me to believe that the drafter of this particular amendment was fully aware of the changes to the law made by Peoples in respect of the duty of care. This approach is in keeping with the rule of statutory interpretation that the legislature is presumed to know the law. ${ }^{45}$

Third, I believe that there is a better analysis than that offered by the Supreme Court in Peoples, and that this analysis may lead to different results in various types of cases.

Despite these differences, it is important to note that it will not be argued that the Supreme Court's view is without analytical foundation. While I believe that the analysis of the Supreme Court is justifiable, I also believe that a different analysis is more intellectually defensible and will lead to more coherent and predictable results for those who are seeking to advise clients as to how to behave to avoid future uncertainty.

43 Paradoxically, the explanatory notes also show that the bill was designed, as part of the modernization of its language, to bring it closer to the language of the $C B C A$, supra note 6 . While in many other respects the bill does accomplish its goal in this regard, this entire article makes it clear that, with respect to the duty of care, the amendments separate the OBCA from the CBCA. Services, 2d Sess., 38th Leg., Ontario, 2006, Explanatory Note (assented to 20 December 2006), S.O. 2006, c. 34. 


\section{A. Is IT OBVIOUs?}

As mentioned above, the Peoples decision significantly broadened the group to whom the statutory duty of care is owed. The Court also held that the civil law of Quebec can be used as suppletive law. ${ }^{46}$ While this is in no doubt correct, the Court goes on to write:

Three elements of art. 1457 C.C.Q. are relevant to the integration of the director's duty of care into the principles of extra-contractual liability: who has the duty ("every person"), to whom is the duty owed ("another") and what breach will trigger liability ("rules of conduct"). It is clear that directors and officers come within the expression "every person." It is equally clear that the word "another" can include the creditors. The reach of art. 1457 C.C.Q. is broad and it has been given an open and inclusive meaning. See Regent Taxi \& Transport Co. v. Congrégation des Petits Frères de Marie, [1929] S.C.R. 650, per Anglin C.J., at p. 655 (rev'd on other grounds, [1932] 2 D.L.R. 70 (P.C.)):

... to narrow the prima facie scope of art. 1053 C.C. [now art. 1457] is highly dangerous and would necessarily result in most meritorious claims being rejected; many a wrong would be without a remedy.

This liberal interpretation was also affirmed and treated as settled by this Court in Lister v. McAnulty, [1944] S.C.R. 317, and Hôpital Notre-Dame de l'Espérance v. Laurent, [1978] 1 S.C.R. 605.

This interpretation can be harmoniously integrated with the wording of the CBCA. Indeed, unlike the statement of the fiduciary duty in s. 122(1)(a) of the CBCA, which specifies that directors and officers must act with a view to the best interests of the corporation, the statement of the duty of care in s. 122(1)(b) of the CBCA does not specifically refer to an identifiable party as the beneficiary of the duty. Instead, it provides that "[e]very director and officer of a corporation in exercising their powers and discharging their duties shall ... exercise the care, diligence and skill that a reasonably prudent person would exercise in comparable circumstances." Thus, the identity of the beneficiary of the duty of care is much more open-ended, and it appears obvious that it must include creditors. This result is clearly consistent with the civil law interpretation of the word "another." Therefore, if breach of the standard of care, causation and damages are established, creditors can resort to art. 1457 to have their rights vindicated. The only issue thus remaining is the determination of the "rules of conduct" likely to trigger extracontractual liability. On this issue, art. 1457 is explicit. $^{47}$

I apologize for the length of the quotation. The point of this length is to provide immediate context for the emphasized words. Prior to the judgment in Peoples, it was by no means obvious that the intention of Parliament in its drafting of s. 122(1)(b) was to create a broad set of beneficiaries.

There are other scholars who had, up to the time of the judgment, apparently agreed that the scope of benefit under the statutory duty of care was limited to the corporation. In 1991, 
Professor Bruce Welling published the second edition of his treatise Corporate Law in Canada: The Governing Principles. ${ }^{48}$ In that volume, Professor Welling wrote:

\begin{abstract}
Essentially, the remedies [for breach of the duty of care] fall within the usual areas of tort or shareholders' remedies created by the statute. As far as tort actions go, the statute has created a duty to the corporation. If the corporation has suffered injury as a result of the director's default, and proximate cause within the tort test can be shown, the corporation may recover damages. The action may be launched by the corporation through a decision of the board of directors, or may be commenced by a shareholder in a representative capacity. ${ }^{49}$
\end{abstract}

Similarly, Quebec corporate law scholar Stéphane Rousseau, in an article published shortly after the judgment in the Peoples case, wrote as follows:

This opinion reverses a fundamental principle of corporate law. At common law, it had long been established that directors, in the performance of their functions, stand in a fiduciary relationship to the corporation to which they owe fiduciary duties and a duty of care. In civil law, directors are the mandataries (or agents) of the corporation and owe their duties to the latter, their mandator (or principal). These duties are meant to ensure the protection of the mandator who trusts the mandatary to manage her affairs. ${ }^{50}$

So, it appears that the Supreme Court's point was not obvious to everyone, or at least was not so until Major and Deschamps JJ. indicated as much in their joint reasons. Even experts, such as Professors Welling (cited repeatedly by the Supreme Court itself on cases involving corporate law issues ${ }^{51}$ ) and Rousseau (based both on common and civil law ${ }^{52}$ ) thought the law was more restrictive prior to Peoples than the Supreme Court of Canada indicates in its decision.

But saying that the Supreme Court's interpretation was not obvious is hardly a convincing argument in and of itself that the Court's exposition of legal principles in the case should have been otherwise. Below, I sketch a two-pronged argument to suggest that the Supreme Court's position, although defensible, is precarious. In my view, the class of beneficiaries to which the statutory duty of care is owed in modern corporate statutes should be restricted to the corporation alone. This argument is based, first, on the Court's reliance on the Civil Code of Québec ${ }^{53}$ in Peoples, and second, on principles of statutory interpretation.

Bruce L. Welling, Corporate Law in Canada: The Governing Principles, 2d ed. (Toronto: Butterworths, 1991).

Ibid. at 336 [emphasis added].

Stéphane Rousseau, “Directors’ Duty of Care After Peoples: Would it be Wise to Start Worrying About Liability?” (2005) 41 Can. Bus. L.J. 223 at 225-26 [emphasis added].

Professor Welling has been cited by the Supreme Court of Canada on issues of corporate law on three different occasions, all in the context of tax cases involving corporations: see McClurg v. Canada, [1990] 3 S.C.R. 1020 [McClurg]; Neuman v. Canada (Minister of National Revenue), [1998] 1 S.C.R. 770 at para. 46; Duha Printers (Western) Ltd. v. Canada, [1998] 1 S.C.R. 795 at para. 61.

Interestingly, the Court cites Professor Rousseau and his co-author Professor Crête in the Peoples decision itself. Admittedly, Professor Rousseau's work is not cited to support a broadening of the duty of care, rather, it is cited to support the argument in favour of harmonization between federal law and its Quebec civil counterpart: see Peoples, supra note 1 at para. 29. Nonetheless, when an author cited by the Court in a decision points out serious issues with that same decision, this should perhaps give the Court cause to think quite seriously about the soundness of the reasoning offered.

S.Q. 1991, c. 64 [Civil Code]. 


\section{B. Reliance ON THE CIVIL CODE OF QUÉBEC}

As made clear above, the Court relied on the Civil Code to justify its conclusions with respect to the duty of care. In the latest edition of Corporate Law in Canada, ${ }^{54}$ Professor Welling writes that, based on Peoples, ${ }^{5}$ the duty of care "might be" owed to more than just the corporation. ${ }^{56}$ Professor Welling's ambivalence with respect to the class of beneficiaries appears to emanate from the fact that in Peoples, the Supreme Court was deciding a Quebec case and its reasoning was explicitly based on articles of the Civil Code ${ }^{57}$ However, if that were truly the intention of the Supreme Court, three interrelated concerns arise.

First, would the CBCA be a truly federal statute if the interpretation of its provisions were to depend on certain underlying legal concepts that could vary substantially from province to province? This issue is particularly acute where one is dealing with the civil law tradition of Quebec and attempting to translate it effectively to the common law provinces. Allowing the particular province from which the dispute in Peoples arose to have a significant impact on the scope of the duty of care is like letting the "tail wag the dog," so to speak.

Second, paradoxically, the public importance of the issues presented by the case is one of the key ingredients to resolving applications for leave to appeal to the Supreme Court. ${ }^{58}$ The public importance of the issue would be substantially reduced if the application of the Court's holdings were only directly applicable to a single province. In other words, the public importance of the judgment is much less if the ruling has no application to the interpretation of other incorporation statutes that use identical, or nearly identical, wording to the $C B C A$, because cases under those statutes would not use Quebec jurisprudence in determining the class of beneficiaries of the duty of care. Thus, notwithstanding Professor Welling's narrow interpretation, the view more likely to be adopted is one that indicates that the Peoples decision applies to the interpretation of the $C B C A$ regardless of the province from which the action may happen to originate. Therefore, reliance on the law of a particular province to justify conclusions of national importance seems incongruous.

Third, given that corporate law is designed to facilitate business, ${ }^{59}$ uncertainty and divergence of statutory interpretation and language is not a positive development. The uncertainty lies in the fact that the Supreme Court of Canada does not state definitively the class of people to whom the duty of care is owed. As was mentioned earlier, the Court declared that "the identity of the beneficiary of the duty of care is much more open-ended, and it appears obvious that it must include creditors." ${ }^{60}$ Therefore, even if the Supreme Court is absolutely and unquestionably correct that the scope of the duty needs to be expanded, the Court does not set out the parameters to allow lawyers to advise clients as to the size of class of potential beneficiaries. This leads to uncertainty. Can a shareholder whose shares lose

$54 \quad$ Bruce Welling, Corporate Law in Canada: The Governing Principles, 3d ed. (Queensland: Scribblers, 2006).

Professor Welling cites part of the paragraph referred to at supra note 47 for this purpose.

Welling, supra note 54 at 331, n. 115.

Ibid.

See Supreme Court Act, R.S.C. 1985, c. S-26, s. 40.

McClurg, supra note 51 at para. 34.

Peoples, supra note 1 at para. 57 [emphasis added]. 
value as a result of a decision by directors sue the directors for breach of the duty of care? If so, do directors not become responsible for the investment of the shareholders as a matter of the duty to take care? If so, this seems to undercut much jurisprudence on the fiduciary duty. For example, the common law, including Peoples, has been clear that the fiduciary duty generally does not extend to individual shareholders. ${ }^{61}$ But, if shareholders are owed a duty of care under the statute, this creates the possibility that a change in the pleading of the case may lead to a result allowed through the back door that would have been prohibited through the front door. ${ }^{62}$

Clearly, the Supreme Court's view of the scope of the duty of care is not shared by the legislators of New Brunswick. ${ }^{63}$ Many provinces, ${ }^{64}$ including Ontario, have legislation that was, at least prior to the Peoples decision, by and large consistent with the CBCA. Now, due to an expansive interpretation by the Supreme Court of the beneficiaries of the duty, Ontario has changed its legislation to clarify the situation. Will this difference in statutory language increase the use of the $O B C A$ over the $C B C A$ ? It may, at least for the sophisticated business person. After all, in most cases, a sophisticated business person who incorporates a business or idea will generally expect to serve as a director of the corporation. Left with the choice of either:

(ii) serving as a director of a corporation incorporated in a jurisdiction that has less

liability for directors to third parties (Ontario),

serving as a director of a corporation incorporated in a jurisdiction that increases liability of directors to third parties (federally); or

See Percival v. Wright, [1902] 2 Ch. 421. Although this is still the general rule, there are cases that move away from it in specific circumstances: see Coleman v. Myers, [1977] 2 N.Z.L.R. 225 (C.A.); Haase $v$. Vladi Private Islands Ltd. (1990), 96 N.S.R. (2d) 323 (C.A.); Hardman Group Ltd. v. Alexander, 2003 NSSC 59, 212 N.S.R. (2d) 304.

62 We will return to this point in Part IV.C.1, below.

63 In the Business Corporations Act, S.N.B. 1981, c. B-9.1, s. 79(1), the section reads as follows:

Every director and officer of a corporation in exercising his powers and discharging his duties shall

(a) act honestly and in good faith, and

(b) exercise the care, diligence and skill that a reasonably prudent person would exercise in comparable circumstances

in the best interests of the corporation.

Whether the closing words are to the same effect as the Ontario amendments is an open question. I believe that they are. As mentioned earlier, the Court in Peoples drew a distinction between the beneficiary of the fiduciary duty (the corporation) and the duty of care (the corporation and others). One of the rationales for this approach was the fact that the closing words of s. 79(1), "in the best interests of the corporation," were present in the former and absent in the duty of care. But, again, this is not the forum in which to resolve this particular issue. It will have to be left to another day. 
which would a sophisticated business person choose? ${ }^{65}$ I suspect the answer would be the latter. This would be consistent with what has been, up to this point, referred to by some as the phenomenon of the "race to the bottom." 66

But what of the other jurisdictions? British Columbia, Alberta, Saskatchewan, Manitoba, Newfoundland and Labrador, the Northwest Territories, Nunavut, and the Yukon Territory all use identical language to that of the $C B C A$ with respect to the duty of care ${ }^{67}$ They do not have the generalized provision of the Civil Code on which to rely in order to justify the Court's conclusion. Also, the law of other provinces (including Quebec) is not a matter mentioned in the interpretation acts ${ }^{68}$ of any of these provinces or territories. This creates a conundrum for the courts of these provinces and territories. On the one hand, the court has a clear statement from the Supreme Court on the interpretation of this statutory language; the doctrine of stare decisis would seem to be applicable. On the other hand, one of the direct bases of the decision is not applicable on the new facts under the provincial statute. What, then, is a court to do? The smart money says that the court will follow the judgment in Peoples, even though the law of Quebec is not a specific interpretive aid in the courts of other provinces when dealing with the provincial equivalents to the $C B C A$. To do otherwise is to fracture a federal statute and create a different $C B C A$ for every jurisdiction.

\section{CANADIAN STATUTORY INTERPRETATION}

The most authoritative statement of the "golden rule" of the construction of statutes in Canadian law belongs to Elmer A. Dreidger. As he put it:

[Today] there is only one principle or approach, namely, the words of an Act are to be read in their entire context in their grammatical and ordinary sense harmoniously with the scheme of the Act, the object of the Act and the intention of Parliament. ${ }^{69}$

Admittedly, the duty of care is not the only substantive difference between the Ontario and federal incorporation statutes. For example, under the $C B C A$, its provision regarding pre-incorporation transactions applies only to written contracts: see $C B C A$, supra note 6 , s. 14 . Under the $O B C A$, on the other hand, the statutory provision applies to both written and oral contracts: see OBCA, supra note 5 , s. 21. However, the scope of the duty of care is a fairly central element to corporate governance, in the sense that it is one of the key elements of managerial responsibility that is mentioned in introductory courses in corporate law. Also, unlike pre-incorporation transactions (which may or may not be applicable to any given corporation), the duty of care is applicable to any Canadian corporation. Thus, it would be reasonable to believe that a business person might take account of this difference in choosing the jurisdiction of incorporation.

$66 \quad$ Louis K. Ligget Co. v. Lee, 288 U.S. 517 at 558-559 (1933) (Brandeis J.) (referring to the "race ... of laxity"). The management-friendly approach to corporate governance in Delaware has been cited as one of the reasons that Delaware has been so successful in its attempt to attract incorporation: see Robert B. Thompson, "Delaware, the Feds, and the Stock Exchange: Challenges to the First State as First in Corporate Law" (2004) 29 Del. J. Corp. L. 779 at 781-82 (discussing the "mission statement" of Delaware corporate law).

67 See supra note 64 .

68 See Interpretation Act, R.S.B.C. 1996, c. 238; Interpretation Act, R.S.A. 2000, c. I-8; The Interpretation Act, 1995, S.S. 1995, c. I-11.2; The Interpretation Act, S.M. 2000, c. 26, C.C.S.M. c. I80; Interpretation Act, R.S.N.L. 1990, c. I-19; Interpretation Act, R.S.N.W.T. 1988, c. I-8 (also used in Nunavut); Interpretation Act, R.S.Y. 2002, c. 125.

69 Elmer A. Driedger, The Construction of Statutes (Toronto: Butterworths, 1974) at 67, quoted with approval in Sullivan, supra note 45 at 1. 
Ruth Sullivan continues this train of thought in the fifth edition of the same text, where she writes as follows:

The legislative scheme. When analyzing the scheme of an Act, the court tries to discover how the provisions or parts of the Act work together to give effect to a plausible and coherent plan. It then considers how the provision to be interpreted can be understood in terms of that plan. The court's reasoning is described by Greschuk J. in Melnychuk v. Heard:

The court must not only consider one section but all sections of an Act including the relation of one section to the other sections, the relation of a section to the general object intended to be secured by the Act, the importance of the section, the whole scope of the Act and the real intention of the enacting body.

The fundamental presumption in scheme analysis is that modern legislation (unlike much early legislation) is not just a series of rules. It typically includes a mix of interpretation provisions, application provisions, office- and institution-establishing provisions, power conferring provisions, dispute resolution provisions and transitional provisions as well as traditional prohibitions and entitlements, all of which are meant to operate together in a particular institutional setting.... Much modern regulatory legislation is lengthy and complex, and the schemes can be difficult to master. However, once mastered such schemes often point quite clearly to the interpretation that gives effect to the legislature's intention. ${ }^{70}$

As I read Sullivan's words, they point to what she calls at another point in the book, the "presumption of coherence" ${ }^{\text {"1 }}$ within a statute. In other words, legislative drafting is not simply an exercise in listing legislative edicts on a particular topic. Rather, a statute, particularly one that is as voluminous and complex as the $C B C A$, is more akin to a tapestry, where provisions are carefully interwoven with one another. If this is the case, then it seems to me that three results flow from this statement. First, two paragraphs within the same subsection should be read so as to be consistent with one another. Second, two different subsections within the same provision should not create inconsistency where a different interpretation is available according to which absurd results do not follow. Finally, where an interpretation of one section would make another section of the same statute redundant or nonsensical, such an interpretation is to be avoided. Let us consider each of these in turn.

\section{Different Paragraphs Within the SAME SubSECTION}

\section{a. The Principle of Statutory Coherence}

As pointed out earlier, first, the statutory fiduciary duty and the statutory duty of care are listed in paras. 122(1)(a) and (b) of the CBCA, respectively. Despite their proximity to one another, the Supreme Court held in Peoples that para. (a) protects only the corporation, while the very next paragraph is much broader in its scope. Is this in keeping with the principle of coherence as set out by Sullivan? I think not. 
To put the matter more mildly, it would be more consistent with the principle of coherence in legislative drafting if the section were read to only benefit the corporation, rather than the broader group identified by the Supreme Court in Peoples. This militates against the holding of the Supreme Court and in my view casts even more serious doubt on the alleged "obviousness" of the reasoning.

\section{b. Increased Liability Creates Self-Interest}

It can also be argued that the expansive view of the duty of care creates problems for the fiduciary duty. It may be helpful to think of this argument as follows. First, a fiduciary duty demands that the fiduciary, such as a director or an officer, put aside self-interest in order to protect the interests of the beneficiary, in this case the corporation. In other words, in terms of the fiduciary duty, self-interest is a bad result. The remedy for breach of fiduciary duty is also indicative of this in that the remedy is generally based on the profit earned by the fiduciary, even if receipt of this profit would not have been available to the beneficiary. ${ }^{72}$ This remedy removes all personal incentive for the fiduciary to breach this duty, thereby preserving the integrity of the fiduciary relationship. ${ }^{73}$ By removing all potential for improper personal gain by the officer, ${ }^{74}$ the law encourages commitment to the corporation's goals, not personal ones. ${ }^{75}$

In terms of the expanded duty of care, however, paradoxically, the law may actually encourage the self-interest of the officer. Imagine, if you would, the following thought process by an officer: I am confronted with a strategy that is quite risky. It is particularly risky for the unsecured creditors of the corporation. There is no immediate risk if we do nothing, other than the loss of the opportunity. There is limited information available on the long-term effects of this proposal. But, the reason for this dearth of information is that the strategy has never been tried. It is very likely that if this does not go well a creditor may be negatively affected. With the expanded duty of care, I could be sued personally.

The expansive version of the duty of care may force the director to be more concerned with his or her potential exposure to lawsuits by creditors. This, in turn, may deter risk-taking by the directors on the corporation's behalf because, if the risk proves unwise, multiple suits by creditors and others against the director personally may follow. Therefore, the increased director liability under the expansive duty of care may cause an increase in self-interest by directors, which is diametrically opposed to the intention of the statutory fiduciary duty.

Even if the suit against directors and/or officers is ultimately unsuccessful, the chilling effect may still be present. The directors and/or officers may spend time and energy in defending the suit of creditors. ${ }^{76}$ If they choose to do so (and it is economically logical to

Strother v. 3464920 Canada Inc., 2007 SCC 24, [2007] 2 S.C.R. 177 [Strother].

Ibid. at paras. 75-77.

See Regal (Hastings) Ltd. v. Gulliver (1942), [1967] 2 A.C. 134 at 378 (H.L.); Canadian Aero Service Ltd. v. O'Malley, [1974] S.C.R. 592 [CanAero].

Strother, supra note 72 at paras. 75-77.

It could be argued that regardless of the pronouncement of the Supreme Court in Peoples, baseless lawsuits cannot be stopped. There is some truth in this statement. However, if the Supreme Court had made a definitive holding that the duty was owed to the corporation alone, then by the rules of civil 
suggest that a director will tend to concentrate efforts on avoiding losses to his or her personal wealth, regardless of its size), this takes their energy away from the business and affairs of the corporation. Therefore, there is, in economic terms, an opportunity cost to the expansion of the duty. ${ }^{77}$ This chilling effect is based on self-interest, regardless of whether the duty of care has in fact been breached by the director or officer.

\section{c. The Business Judgment Rule}

To be fair to the Supreme Court, it must be pointed out that the Court tried to deal with the issue identified in the previous section through the application of the business judgment rule. However, there are two fundamental problems with this "solution."

The first is a paradox within the paradox. One formulation of the business judgment rule says that the rule only shields director decisions that are reasonable both in terms of the process followed by the directors and in terms of the substance of the decision reached. ${ }^{78}$

The problem with this approach is that reasonableness is the touchstone of the business judgment rule, as well as the touchstone of the duty of care. Put another way, can a decision be reasonable in both process and result if a director did not exercise the care, diligence, and skill that a reasonably prudent person would have exercised in comparable circumstances? When expressed in those terms, it seems likely that the protection of the business judgment rule would rarely (if ever) save what would otherwise be a breach of the duty of care by directors. This would seem to suggest that the potential application of the business judgment rule does not necessarily provide the level of protection that the Supreme Court may have intended in its judgment in Peoples.

But this is not the only way that the business judgment rule has been defined by the courts. In CW Shareholdings Inc. v. WIC Western International Communications Ltd., ${ }^{79}$ the Court held as follows:

In assessing whether or not directors have met their fiduciary and statutory obligations, as outlined earlier in these reasons, Canadian courts have generally approached the subject on the basis of what has become known as the "business judgment rule." This rule is an extension of the fundamental principle that the business and affairs of a corporation are managed by or under the direction of its board of directors. It operates to shield from court intervention business decisions which have been made honestly, prudently, in

procedure, the director or officer at issue could easily, quickly, and relatively inexpensively put an end to the lawsuit: see e.g. Manitoba, Court of Queen's Bench Rules, r. 20.03(1). With the scope of the duty being very uncertain, on the other hand, there can be a tendency to begin lawsuits, if only as a legal strategy. In some cases, this strategy is designed to induce faster settlement of disputes, or alternatively, to secure other advantages in resolution discussions. One such advantage might be that the plaintiff will agree to forego the suit against the director if the suit against the corporation is settled on terms acceptable to the plaintiff.

77 In addition, there is the potential for a more immediate, direct, and tangible cost to the corporation, through either voluntary (CBCA, supra note 6, s. 124(1)) or mandatory (CBCA, supra note 6, s. 124(5)) indemnification. We will return to the subject of indemnification below.

78 UPM-Kymmene Corp. v. UPM-Kymmene Miramichi Inc. (2004), 250 D.L.R. (4th) 526 at paras. 5-7 (Ont. C.A.) [UPM].

79 (1998), 39 O.R. (3d) 755 (Gen. Div.). 
good faith and on reasonable grounds. In such cases, the board's decisions will not be subject to microscopic examination and the court will be reluctant to interfere and to usurp the board of director's function in managing the corporation. The oft-cited remarks of Anderson J. in Brant Investments v. KeepRite Inc. made in the context of an oppression remedy hearing — are apt in this regard. At pp. 759-60, he said:

The jurisdiction [to review] is one which must be exercised with care. On the one hand the minority shareholder must be protected from unfair treatment; that is the clearly expressed intent of the section. On the other hand the court ought not to usurp the function of the board of directors in managing the company, nor should it eliminate or supplant the legitimate exercise of control by the majority.... Business decisions, honestly made, should not be subjected to microscopic examination. There should be no interference simply because a decision is unpopular with the minority. ${ }^{80}$

I leave aside the fact that even in this formulation of the business judgment rule, reasonableness is still part of the equation. The question with this formulation is one of certainty. To say that decisions will not be subject to "microscopic examination" by the court is helpful, but does not provide much guidance to either business people or the counsel who are paid to advise them as to what level of examination can be reasonably expected in order to inform future conduct. It provides no meaningful guidance as to when or to what degree the court will re-examine board decisions, other than that courts should not usurp the role of directors or become involved simply because the decision is unpopular. ${ }^{81}$

Ibid. at 774 [emphasis added].

If anything, BCE, supra note 7 at para. 87, only helps to further complicate the analysis. There, the Supreme Court writes: "What is clear is that the Revlon line of cases has not displaced the fundamental rule that the duty of the directors cannot be confined to particular priority rules, but is rather a function of business judgment of what is in the best interests of the corporation, in the particular situation it faces.” In the same case, the Court writes: "The business judgment rule expresses the need for deference to the business judgment of directors as to the best interests of the corporation” (at para. 140) [emphasis in original].

The Court, in both Peoples and BCE, is at pains to distinguish the fiduciary duty (which is primarily concerned with loyalty and the avoidance of a conflict of interest) from the duty of care (which is concerned with ensuring that decision-makers have before them the information relevant to the decision being made, and take into account all of the relevant considerations). The two duties, according to the Court, are owed to two different groups of beneficiaries (though, admittedly, the corporation is owed both duties), despite the fact that the two duties are found in the same section of the CBCA.

However, the excerpts quoted serve to point out how the Court sometimes conflates the two duties. The phrase "best interests of the corporation" is associated with the fiduciary duty, and in fact drawn directly from the wording of the CBCA, supra note 6, s. 122(1)(b). The application of business judgment, on the other hand, harkens to the duty of care. Business judgment by directors cannot save what is otherwise an impermissible conflict of interest by one of them. Yet, the Court uses both phrases in the same sentence. The application of careful business judgment will be a factor in determining whether there is a breach of the duty of care. But, careful judgment does not seem to assist with an alleged breach of the fiduciary duty: see e.g. CanAero, supra note 74. In that case, even though the directors had been careful to quit their jobs before pursuing an opportunity that was also being sought by their former employer, it did not negate their liability for breach of fiduciary duty. The care that the defendants had taken in this regard was not even mentioned by the Court. Liability was imposed despite their care. Yet, the Court in $B C E$ appears to want to apply the two concepts side by side. Further, in BCE, supra note 7 at para. 155, the Court writes: “As Lax J. stated in UPM-Kymmene Corp. v. UPM-Kymmene Miramichi Inc. (2002), 214 D.L.R. (4th) 496 (Ont. Sup. Ct. J.), at para. 153: ‘Although Board decisions are not subject to microscopic examination with the perfect vision of hindsight, they are subject to examination."” The reliance on the UPM case is interesting because the case clearly divided the fiduciary duty from the duty of care. One director was alleged and found to have breached his fiduciary duty to the corporation by virtue of a self-interested transaction (at paras. 115-23). The other directors were alleged to have 


\section{d. The Narrower Version of the Duty of Care}

If the duty of care were restricted to the corporation as its sole beneficiary (the narrow approach to the duty of care), in general, none of the issues identified above are as problematic. With respect to the principle of coherence, clearly, it is more consistent to say that both the duty of care and the fiduciary duty are owed to the same class of beneficiaries. With respect to the paradoxical impact of expanded liability, this is also avoided. The director is always pulled in the same direction by both the fiduciary duty and the duty of care. In order to prevent personal liability under the duty of care, the director has to do what he or she believes is in the long-term interests of the corporation as a whole, ${ }^{82}$ thereby also fulfilling the director's fiduciary obligations to the corporation. Finally, by reducing the number of beneficiaries to whom the duty is owed, the uncertainty of the application of the business judgment rule is concomitantly reduced. Furthermore, by ensuring that only corporate participants can access the duty of care, the potential for the uncertainty to wreak havoc is reduced.

breached the duty of care by not enquiring sufficiently into the terms of the transaction prior to its approval (at paras. 124-51). The business judgment rule could have protected the other directors (at paras. 152-56), but was never discussed in the context of protecting the self-interested director from the allegation of the breach of fiduciary duty. The Supreme Court does not seem to recognize this distinction.

82 CBCA, ibid., s. 122. This, of course, leaves aside entirely the issue of what constitutes the "best interests of the corporation" for the purposes of the fiduciary duty. In my view, Peoples missed the mark on this point. The "best interests of the corporation" as referred to in the CBCA should be interpreted to mean the "best interests of the shareholders collectively." This is the position rejected by the Supreme Court in Peoples, supra note 1 at para. 42, and further reinforced by BCE, ibid. at para. 84. The shareholders of a corporation are the residual beneficiaries of its value. They also generally have relatively little chance to control corporate actions, other than the election of directors. Therefore, in considering the best interests of the corporation, the directors need not look to the best interests of those other groups. Creditors, on the other hand, can write covenants or restrictions into their agreements with the corporation, should the need arise. Directors duties constitute one of the control mechanisms for shareholders. The protections that particular types of creditors may need can be dealt with separately. For example, employees are given the right to sue the directors to recover as much as six months wages if the corporation goes bankrupt: see CBCA, ibid., s. 119. Also, under the Bankruptcy and Insolvency Act, R.S.C. 1985, c. B-3, s. 81.1, trade creditors are entitled to the return of any goods of the trade seller sold to the bankrupt within the last 30 days prior to bankruptcy for which the trade seller has not been paid at the date of bankruptcy. An educated person might suggest that this is short-sighted. After all, if a business does not look after its creditors, customers, employees, and others, it will not be in business very long. I agree with the latter assertion, but not that a focus on shareholder value leads to shortsighted behaviour by directors. This speaks merely to the consideration of how best to reach the goal of business success, rather than answering the following question: according to whose measure is business success judged? One must consider all of these constituencies, but to what end? Is serving the creditors or the environment, or any other constituency for that matter, the end goal of the corporation? In business, the object is economic, and therefore, the goal of the corporation must be to serve the economic beneficiaries, that is, the shareholders. So, in the end, the fiduciary duty does not tell the directors to ignore all constituencies other than shareholders. Rather, it says only that the needs of these other constituencies are only relevant to the extent that they impact the end goal that the corporation wishes to achieve. If a reader is interested in a fuller explanation of the author's views on this point, see Darcy L. MacPherson, “The Supreme Court Restates Directors’ Fiduciary Duty - A Comment on Peoples Department Stores v. Wise” (2005) 43 Alta. L. Rev. 383. 


\title{
2. Different Subsections Within the SAme Section
}

\section{a. Absurdity in Statutory Interpretation}

If the Court's holdings in Peoples are taken at face value, some very strange results could follow. In fact, one could even call these results legally absurd. As Sullivan explains:

\begin{abstract}
Relevance of consequences in interpretation. When a court is called on to interpret legislation, it is not engaged in an academic exercise. Interpretation involves the application of legislation to facts in a way that affects the well-being of individuals and communities for better or worse. Not surprisingly, the courts are interested in knowing what the consequences will be and judging whether they are acceptable. Consequences judged to be good are presumed to be intended and generally are regarded as part of the legislative purpose. Consequences judged to be contrary to accepted norms of justice or reasonableness are labelled absurd and are presumed to have been unintended. If adopting an interpretation would lead to absurdity, the courts may reject that interpretation in favour of a plausible alternative that avoids the absurdity. ${ }^{83}$
\end{abstract}

In other words, a results-based analysis of statutory provisions is both acceptable and expected.

\section{b. A Hypothetical to Assist with Our Analysis}

A hypothetical example might assist in our consideration of this issue: a corporation seeks to borrow money from a financial institution and a contract is drawn up. In this contract, it is made clear that the corporation alone, and not any of its directors, officers, or other employees, is responsible for the payment under the contract. All claims made by the financial institution are to be made against the corporation, regardless of their source (contractual or tortious). The contract also specifically provides that all employees, including directors and officers of the corporation, are entitled to the protection of these clauses insofar as they are carrying out the contractual obligations of the corporation in performing the activity later found to be negligent. The corporation's liability is limited to $\$ 100,000$.

Later, owing to the negligence of several employees and the negligent supervision by a person who is both an officer and director of the corporation, the financial institution suffers a loss to its own account because of the negligent actions. The financial institution wishes to sue to recover its loss.

Several legal consequences flow from this hypothetical fact scenario. ${ }^{84}$ First, the law of contracts specifically provides that a duty of care in tort and equity may be circumscribed

$83 \quad$ Supra note 45 at 299.

84 In fact, this "hypothetical" is not a hypothetical at all. The facts presented closely mirror the facts in London Drugs Ltd. v. Kuehne \& Nagel International Ltd., [1992] 3 S.C.R. 299 [London Drugs]. There are three differences between London Drugs and this hypothetical. First, in London Drugs, the suit was against regular employees and not directors or officers. Second, the negligence resulted in damage to property, a transformer, as opposed to a financial loss. Third, in London Drugs, there was a limitation of liability clause and not an exclusion of liability on officers and directors entirely. Nonetheless, in my view, none of these differences undermine the validity of the analogy made herein. 
either by contractual agreement ${ }^{85}$ or by other means. ${ }^{86}$ Thus, the liability of the corporation is limited by a properly drafted contract. In this case, liability is limited to $\$ 100,000$. Second, the law regarding privity of contract (as defined in London Drugs) would generally allow any corporate employee to seek the protection of the exclusion of liability clause, as long as there was an intention to provide such coverage. ${ }^{87}$ In other words, the contractual arrangements between the parties preclude an allegation by the financial institution of a breach of the duty of care by the employees. Therefore, the negligent employees who committed the acts that led directly to the loss would be entitled to the benefit of the limitation of liability clause. Hence, their liability would also be excluded.

\section{c. The Impact of Section 122(3)}

However, according to the Court's judgment in Peoples, in combination with the provisions of the $C B C A$, the situation could be quite different for the director and officer of the corporation. ${ }^{88}$ According to Peoples, the financial creditor can base a claim against the officer and director on the basis of a breach of the statutory duty of care. Furthermore, according to s. 122(3), "no provision in a contract ... relieves a director or officer from the duty to act in accordance with this Act or the regulations or relieves them from liability for a breach thereof." ${ }^{89}$ Based on this section, the CBCA is quite clear that if a director or officer breaches his or her duty of care (or any other section of the CBCA, for that matter), no contractual limitation should operate to reduce or excuse the liability that would otherwise attach. Thus, unlike the corporation itself and the employees whose negligence led directly to the loss complained of, the director and officer (whose negligence led only indirectly to the loss complained of) cannot rely on the exclusion of liability clause, since this would run directly counter to s. 122(3).

Clearly, this is an absurd result. The Supreme Court of Canada made a substantial argument in favour of forcing commercial parties to stay within the terms bargained for between themselves in London Drugs. There, Iacobucci J., speaking for the majority, made a policy-based argument to justify the extension of privity of contract to employees who were implicitly or explicitly meant to be covered by contractual provisions. He wrote as follows:

The doctrine of privity fails to appreciate the special considerations which arise from the relationships of employer-employee and employer-customer. There is clearly an identity of interest between the employer and his or her employees as far as the performance of the employer's contractual obligations is concerned. When a person contracts with an employer for certain services, there can be little doubt in most cases that employees will have the prime responsibilities related to the performance of the obligations which arise under the contract. This was the case in the present appeal, clearly to the knowledge of the appellant. While such

See BG Checo International Ltd. v. British Columbia Hydro and Power Authority, [1993] 1 S.C.R. 12 at paras. 17-21; London Drugs, ibid. at 458; Strother, supra note 72.

Edgeworth Construction Ltd. v. N.D. Lea \& Associates Ltd., [1993] 3 S.C.R. 206 at para. 22.

London Drugs, supra note 84.

For these purposes, both directors and officers owe the statutory duty of care. In other cases, there can be differences between the liability of officers and directors, such as the use of the "safe harbour" provisions referred to earlier. However, those provisions, and the potential difficulties that differential treatment could create, are not at issue in the argument made here.

CBCA, supra note 6, s. 122(3) [emphasis added]. 
a similarity or closeness might not be present when an employer performs his or her obligations through someone who is not an employee, it is virtually always present when employees are involved.... However, when an employer and a customer enter into a contract for services and include a clause limiting the liability of the employer for damages arising from what will normally be conduct contemplated by the contracting parties to be performed by the employer's employees, and in fact so performed, there is simply no valid reason for denying the benefit of the clause to employees who perform the contractual obligations. The nature and scope of the limitation of liability clause in such a case coincides essentially with the nature and scope of the contractual obligations performed by the third party beneficiaries (employees).

Upholding a strict application of the doctrine of privity in the circumstances of this case would also have the effect of allowing the appellant to circumvent or escape the limitation of liability clause to which it had expressly consented. ${ }^{90}$

In both London Drugs and the hypothetical above, the law could potentially create two defendants (in the case of London Drugs, the corporation and the employees; in the hypothetical, the corporation and the officer and director) for a single plaintiff (the client in the case of London Drugs, and the financial institution in the hypothetical) to sue for a single wrong (in the case of London Drugs, negligence; in the hypothetical, the breach of the statutory duty of care). The import of the finding in London Drugs is that this can be problematic where there is an identity of interest between the two defendants and the contract between the plaintiff and the other contracting party deals with the situation. In London Drugs, the Court was explicit that contracting parties should not be allowed to use the law to alter the explicit allocations of risk represented by the contract. On this subject, Iacobucci J. wrote as follows:

Many have noted that an application of the doctrine so as to prevent a third party from relying on a limitation of liability clause which was intended to benefit him or her frustrates sound commercial practice and justice. It does not respect allocations and assumptions of risk made by the parties to the contract and it ignores the practical realities of insurance coverage. In essence, it permits one party to make a unilateral modification to the contract by circumventing its provisions and the express or implied intention of the parties. In addition, it is inconsistent with the reasonable expectations of all the parties to the transaction, including the third party beneficiary who is made to support the entire burden of liability. The doctrine has also been criticized for creating uncertainty in the law. While most commentators welcome, at least in principle, the various judicial exceptions to privity of contract, concerns about the predictability of their use have been raised. Moreover, it is said, in cases where the recognized exceptions do not appear to apply, the underlying concerns of commercial reality and justice still militate for the recognition of a third party beneficiary right. ${ }^{91}$

The emphasized portion of this quotation makes it clear that the Supreme Court of Canada is generally in favour of

(i) upholding sound commercial practice;

(ii) respecting allocations and assumptions of risk by the parties; 
(iii) taking account of the realities of insurance coverage; and

(iv) upholding the intentions and reasonable expectations of the parties expressed or implied in contractual provisions and preventing their unilateral circumvention.

These are and should be policy goals of a commercially sensitive and just society. ${ }^{92}$

However, in the hypothetical, none of these results would be upheld if the director and officer cannot rely on the limitation due to the application of s. 122(3). In my view, in the same way that the strict application of privity on the facts of London Drugs would have undermined sound commercial practice and essentially run roughshod over the intentions of the parties, the same could be said if a director and officer could not rely on the limitation of liability clause in the hypothetical.

\section{d. The Advantages of the Common Law}

Some differences exist between London Drugs and the hypothetical. In London Drugs, the legal impediment to achieving a "just result" was a common law doctrine, that is, privity of contract. In the hypothetical, the problem, at least in the narrow sense, lies in the application of a statutory provision, that is, s. 122(3) of the CBCA. The common law is more easily altered by judicial edict than are statutes. In my view, the wording of the subsection is plain and unambiguous. Thus, s. 122(3) is only capable of one interpretation.

Statutory interpretation remains in the bailiwick of judges. In Peoples, the Supreme Court extended the class of beneficiaries of the statutory duty of care, thus causing a disconnect of statutory interpretation between the application of ss. 122(1)(b) and 122(3). It may be helpful to think of it this way: if, contrary to the finding in Peoples, the sole beneficiary of the statutory duty of care was the corporation, a creditor who sought to sue a director or officer for negligence could not do so pursuant to para. 122(1)(b). However, as will be discussed below, the common law provides a potential solution. The common law does not have an equivalent to s. 122(3) of the CBCA. Therefore, as mentioned earlier, the liability under both the common law of negligence ${ }^{93}$ and equitable obligations ${ }^{94}$ may be altered by the contract between the parties. Thus, any contractual provision sought to be invoked to limit liability of the officer or director would not run afoul of s. 122(3). This is because the creditor's cause of action could not be based on a violation of the statute by the officer or director. Rather, the action would be based on the common law of negligence. Thus, s. 122(3) would not apply as it would be restricted to violations of the CBCA or the regulations promulgated thereunder.

To be clear, I do not mean to suggest either that (i) commercial sensitivity is or should be the predominant policy goal of any society; or (ii) that these are the only policy goals that law should seek to serve in a commercial context. My point is simply this: in my view, the Supreme Court was correct to place emphasis on these policy issues and the Court arrived at what I believe is a workable policybased solution to problems based on the law of privity of contract. 
So, if the argument made herein is convincing, the same court that was so concerned about the intention of the parties in London Drugs is now seemingly unconcerned about those same policy oriented issues in a similar context in Peoples. The two results seem so incongruous that, in my view, one cannot stand alongside the other. The Ontario amendments resolve this issue. By ensuring that the statutory duty of care is only extended to the corporation, the Ontario amendments avoid the negative policy consequences created by the Supreme Court through its interpretation of the statutory duty of care in Peoples. If the statutory duty of care were interpreted restrictively, in line with the Ontario amendments, then s. 122(3) would not apply, and thus, any contractual allocation of risk with respect to the potential liability of any director or officer could be acknowledged and enforced without violating the statute.

If we take the narrower view of the duty of care, however, s. 122(3) makes more sense. The point of the duty of care, in the narrow sense, is to protect the corporation from the inattention of its own directors. While the fiduciary duty is designed to avoid director conflicts of interest, the duty of care avoids the situation of directors making decisions for a corporation where the director does not have a basic understanding of the company's business. If the director has such an understanding, but the director does not have the requisite information to adequately protect the company's interests, the duty of care is also violated. If: (i) this were accepted as the basic premise of the duty of care; and (ii) the duty of directors is limited such that it is owed only to the corporation, then the specific references in s. 122(3) excusing liability for the breach of the duty of care by a provision in the articles or bylaws are more easily explained. After all, resolutions and bylaws are used by directors to make major decisions on the company's behalf. Without s. 122(3), these mechanisms could then be used by the person who owes the duty to erase liability to the beneficiary. The corporation cannot be reasonably expected to protect itself from director wrongdoing. Therefore, s. 122(3) removes one of the powerful ways in which directors can attempt to protect themselves against the plaintiff corporation. This is quite logical in that the fiduciary duty says that the directors are not supposed to protect themselves first, but rather protect the corporation. Directors should not be able to protect their own interests at the expense of the corporation.

With respect to creditors, the situation is quite different depending on whether the creditors are voluntary or involuntary. Justice La Forest, in partial dissent in London Drugs, explains the distinction between the two types of creditors:

The distinction between voluntary and involuntary creditors is also useful in this area. As commentators have pointed out (Halpern, Trebilcock and Turnbull, “An Economic Analysis of Limited Liability in Corporation Law” (1980), 30 U.T.L.J. 117), different types of claimants against the corporation have differing abilities to benefit from being put on notice with respect to the impact of the limited liability regime. At one end, creditors like bond holders and banks are generally well situated to evaluate the risks of default and to contract accordingly. These "voluntary" creditors can be considered to be capable of protecting themselves from the consequences of a limited liability regime and the practically systematic recourse by banks to personal guarantees by the principals of small companies attests to that fact.

At the other end of the spectrum are classic involuntary tort creditors exemplified by a plaintiff who is injured when run down by an employee driving a motor car. These involuntary creditors are those who never 
chose to enter into a course of dealing with the company and correspond to what I have termed as the classic vicarious liability claimant. ${ }^{95}$

Voluntary creditors, in particular, can protect themselves through contractual provisions, such as specific clauses to allocate specific types of liability clauses and the like. ${ }^{96}$ Just as there was little reason to protect the property owner in London Drugs because the risk of damages was already allocated by contract, there is little reason for the law to protect voluntary creditors who can negotiate the necessary protections. Generally, the law will often protect those who cannot protect themselves. However, it rarely seeks to protect those who are capable of protecting their own interests but choose not to do so.

Truly involuntary creditors do not choose to deal with the corporation. ${ }^{97}$ Therefore, the law does not expect the involuntary creditor to look after its own interests. Clearly, the expansion of the duty of care would be one way to protect involuntary creditors. However, two interrelated questions remain. The first is whether this is necessary given other protections that exist. The second is whether this result would be reasonable in the circumstances.

When there is tortious conduct by a corporate employee, the nearly automatic application of vicarious liability principles is designed to provide a second source of recovery for damage suffered. According to the partial dissent of La Forest J. in London Drugs, vicarious liability serves the following policy goals:

(i) the corporation is expected to have deeper pockets than the employee who committed the tortious act, and therefore, holding the corporation vicariously liable increases the likelihood of recovery;

(ii) the employee is generally advancing the economic interests of the corporate employer;

(iii) the employer is better suited to distribute losses to others, through its pricing structures and insurance;

(iv) it encourages proper supervision of corporate employees by management. ${ }^{98}$

The above policy goals, according to La Forest J., justify vicarious liability imposed on corporate employers for the acts of their employees in the course of employment. With this, I am in wholehearted agreement. I recognize that, unlike true vicarious liability principles,

95 London Drugs, supra note 84 at paras. 67-68. Interestingly, La Forest J. said that these are not the only categories of creditor. This would be the case where, for example, as in London Drugs, there was a contract and the owner of the property was dealing with the storage company voluntarily but the occurrence at issue was a tortious one, meaning that the damage was involuntary. Therefore, the particular claimant occupied a middle ground between the two extremes described.

$96 \quad$ Ibid.

$97 \quad$ Ibid.

$98 \quad$ Ibid. at paras. 194-97. 
(which apply to the corporate employer liable), a certain degree of fault would have to be proven against the director at issue. ${ }^{99}$

However, La Forest J. offers some meaningful insight into the extension of liability in the corporate context more generally as well. Therefore, the question becomes: does the same hold true for corporate directors and officers? First, typically, the director does not usually have deeper pockets than the corporation to pay debts owing to the involuntary creditor, though admittedly the director may have deeper pockets than the employee who committed the underlying conduct.

Second, it is not the personal interests of the director that are being advanced by the corporate employee. The fiduciary duty requires that the personal interests of the director be subrogated to the interests of the corporation. However, the expanded duty of care makes a director financially responsible for wrongdoing that was never meant to favour the director's interests.

Third, though director and officer liability insurance is available to the managers of some corporations, this is not universal. Levels of coverage and exclusion can also vary. Further, other methods of loss distribution, such as increased prices, which can help to defray costs associated with vicarious liability of the corporation for employee conduct, are unavailable to the individual director.

Fourth, the level of deterrence that is required of directors is dependent on the situation of the particular director. For example, there are executive directors who are part of the dayto-day management of the corporation and non-executive, or outside, directors who are not part of the operations of the corporation. One might think that the need for possible deterrence of the former would be greater than that required to deter the latter. After all, the executives have the ability to supervise employees to a far greater extent than outside directors. The point of having outside directors is to receive a detached perspective; people who can provide sober counsel to the executives with respect to the plans and ideas presented by the board from time to time.

Given the different perspectives of the different groups of directors, one might suggest that this should be reflected in the application of the duty of care. One may respond to the deterrence of increased liability; the other may not. Yet, the purely objective duty of care espoused by the Court in Peoples may not allow for such distinctions given that they are unique to the role of the particular director in the corporation and thus subjective to the

$99 \quad$ Some may also point out that La Forest J. was not even able to convince his colleagues of the correctness of his approach in London Drugs. While this is true, that result may have been dictated by a desire to alter the law of privity or tort, rather than a belief that La Forest J.'s discussion on the principles standing behind the law of vicarious liability of employers for the actions of employees was in error. In the end, I am not attempting to suggest anything more than the idea that one could apply a similar analysis to that offered by La Forest J. If one were to do so, such an analysis would lead to very different results than the ones that are likely to follow from the Supreme Court's reasoning in Peoples. 
particular director at issue. ${ }^{100}$ Does an outside director have to take the same steps to protect the corporation as does the executive director? If so, is this reasonable in the circumstances? I would certainly think not, but I do not claim to have the empirical data to corroborate this conclusion. At the very least, in my view, increasing liability on outside directors may or may not serve the goal of deterrence.

Therefore, while the four points referred to by La Forest J. may indeed make a compelling argument in favour of vicarious liability for the employer with respect to the acts of a corporate employee, these same factors, such as insurance, would not militate as strongly in favour of the expanding liability of directors. With respect to other factors, such as the pursuit of the goals of the corporation, they would unequivocally militate against liability.

Furthermore, two additional and interrelated points require mention. First, the majority judgment in London Drugs makes it clear that the individual employee who commits the tortious act is liable for the damages that result from it. ${ }^{101}$ In addition, the employer is also responsible based on vicarious liability principles. If directors and officers are also liable for failure to provide adequate supervision, this creates a third pool of money from which recovery can be sought. If this is the effect of the judgment in Peoples, I ask simply: how much is too much? I do not intend to answer this question definitively in this article, but there is undoubtedly an argument that, at a certain point, there is a reduced need to add more potential sources of recovery for a civil plaintiff. Where the need for additional sources of recovery is less than compelling, why does the law seek to create them?

\section{e. Indemnification}

Notwithstanding s. 122(3), there is the possibility of indemnification of officers and directors in s. 124 of the $C B C A$. However, in a civil case, such as a negligence action brought against a director for breach of the duty of care, s. 124(5) makes the possibility of mandatory indemnification for costs unlikely. Subsection 124(5) reads as follows:

100 This conclusion is further buttressed by the fact that, in Peoples, the Supreme Court of Canada specifically disapproves of describing the standard of care of directors as "objective/subjective" (Peoples, supra note 1 at para. 63). Justices Major and Deschamps write as follows: "We prefer to describe it as an objective standard. To say that the standard is objective makes it clear that the factual aspects of the circumstances surrounding the actions of the director or officer are important in the case of the s. 122(1)(b) duty of care, as opposed to the subjective motivation of the director or officer, which is the central focus of the statutory fiduciary duty of s. 122(1)(a) of the CBCA” (at para. 63). To me, the distinction between actions (which are part of the objective analysis) and motivation (which is not) is not all that helpful to this analysis. The distinction between executive and outside directors is at least a partial basis for the decision in Soper, supra note 22 at paras. 43-49, describing the standard of care as “objective subjective." The distinction between executive and outside directors is said to be part of the subjective element of the duty of care (at para. 49). Now that the Supreme Court has banished the subjective element in the duty of care, is the distinction between executive and outside directors no longer relevant? If so, this is indeed problematic. The same level of attention to corporate affairs cannot be reasonably expected from an outside director (who may spend one or two days a month on corporate business) as is expected from an executive who sits on the board, spending all of their working hours focused on the business and affairs of the corporation. One hopes that the Supreme Court did not intend otherwise. However, given the discussion of Soper, the resolution of this issue is hardly clear. 


\begin{abstract}
Despite subsection (1) [the subsection allowing for indemnity], an individual referred to in that subsection [directors and officers, amongst others] is entitled to indemnity from the corporation in respect of all costs, charges and expenses reasonably incurred by the individual in connection with the defence of any civil, criminal, administrative, investigative or other proceeding to which the individual is subject because of the individual's association with the corporation or other entity as described in subsection (1), if the individual seeking indemnity (a) was not judged by the court or other competent authority to have committed any fault or omitted to do anything that the individual ought to have done; and (b) fulfils the conditions set out in subsection (3). ${ }^{102}$
\end{abstract}

There are several problems with viewing s. 124(5) as a potential solution in this context. The first of these is a very practical concern. The director or officer would have to go through the rather grueling experience of a trial before knowing whether indemnity is possible. Even if the corporation were prepared to commit itself to providing the indemnity in the absence of a trial by advancing costs, this does not apply to s. $124(5) .{ }^{103}$ In addition, there is no right to indemnity if a court finds that the director is at fault either by commission or omission. Therefore, if there is negligence on the part of the director, mandatory indemnification of the director or officer is unavailable.

\title{
f. Does BCE Change Anything?
}

There is an argument that the Supreme Court has already dealt with some of these issues by holding that the breach of the duty of care is not independently actionable. In this regard, it is necessary to reproduce part of the judgment in $B C E$ :

A second remedy lies against the directors in a civil action for breach of duty of care. As noted, s. 122(1)(b) of the $C B C A$ requires directors and officers of a corporation to "exercise the care, diligence and skill that a reasonably prudent person would exercise in comparable circumstances”. This duty, unlike the s. 122(1)(a) fiduciary duty, is not owed solely to the corporation, and thus may be the basis for liability to other stakeholders in accordance with principles governing the law of tort and extracontractual liability: Peoples Department Stores. Section 122(1)(b) does not provide an independent foundation for claims. However, applying the principles of The Queen in right of Canada v. Saskatchewan Wheat Pool, [1983] 1 S.C.R. 205, courts may take this statutory provision into account as to the standard of behaviour that should reasonably be expected.

A third remedy, grounded in the common law and endorsed by the CBCA, is a s. 241 action for oppression. Unlike the derivative action, which is aimed at enforcing a right of the corporation itself, the oppression remedy focuses on harm to the legal and equitable interests of stakeholders affected by oppressive acts of

CBCA, supra note 6, s. 124(5) [emphasis added].

103 Advancement of costs is covered in s. 124(2), which reads as follows: “A corporation may advance moneys to a director, officer or other individual for the costs, charges and expenses of a proceeding referred to in subsection (1). The individual shall repay the moneys if the individual does not fulfill the conditions of subsection (3)." As a matter of statutory interpretation, the subsection begins with "A corporation may," signifying a voluntary choice. If the corporation chooses not to indemnify, advance costs cannot be forced upon it. Advancement of costs applies to voluntary indemnification pursuant to s. 124(1). While most corporations would choose to indemnify the director or officer voluntarily, not all would do so, and therefore, it cannot be considered as a viable solution for the problem considered here. 
a corporation or its directors. This remedy is available to a wide range of stakeholders — security holders, creditors, directors and officers. ${ }^{104}$

Some people may argue that the first paragraph of the excerpt is meant to preclude liability under s. 122(1)(b). Rather, such liability flows from the fact of negligence, not for breach of the statutory section. Therefore, the Court has clarified that liability is supposed to be determined by the common law of negligence and not the statute.

My response to this argument is fourfold. The first is based on Peoples itself. The Court clearly laid out that the duty of care was owed to creditors. The Court cannot create a right, in this case a duty to creditors, without providing a remedy for its breach, particularly where the Court had gone out of its way to identify both the existence of the right as well as the group to which it is owed. To say that one is owed a duty of care by the statute, but that liability for breach does not begin with the statute seems most illogical.

Second, to give this interpretation to the words of the Supreme Court is to rob s. 122(3) of much of its effect. After all, the section says that no contract, article, bylaw, resolution, and so on, can relieve any liability for the breach of any directors duties. To carve out an exception to this rule for one of the most important duties seems incongruous to say the least. It becomes all the more puzzling when one considers that the section is specifically subject to s. 146(5), which reads as follows:

To the extent that a unanimous shareholder agreement restricts the powers of the directors to manage, or supervise the management of, the business and affairs of the corporation, parties to the unanimous shareholder agreement who are given that power to manage or supervise the management of the business and affairs of the corporation have all the rights, powers, duties and liabilities of a director of the corporation, whether they arise under this Act or otherwise, including any defences available to the directors, and the directors are relieved of their rights, powers, duties and liabilities, including their liabilities under section 119 , to the same extent. ${ }^{105}$

This subsection could not be clearer. There is no distinction between the statutory fiduciary duty and the statutory duty of care. In fact, the language makes it abundantly clear that all obligations and liabilities of directors are transferred, regardless of their source. Since s. 122(3) is specifically subject to s. 146(5), it would be completely nonsensical to have the subject section be broader than the section to which it is subject. To suggest that a statement of the Court drives this legal result is perplexing.

Third, the Court's reliance in BCE on Saskatchewan Wheat Pool ${ }^{106}$ is most curious. In this case, the Saskatchewan Wheat Pool delivered infested grain to the Canadian Wheat Board, ${ }^{107}$ contrary to the Canada Grain Act. ${ }^{108}$ The Canadian Wheat Board sued the Saskatchewan

$B C E$, supra note 7 at paras. $44-45$.

CBCA, supra note 6, s. 146(5) [emphasis added].

Her Majesty The Queen in right of Canada v. Saskatchewan Wheat Pool, [1983] 1 S.C.R. 205

[Saskatchewan Wheat Pool].

Ibid. at 206.

R.S.C. 1985, c. G-10. 
Wheat Pool for breach of the statute without alleging negligence on the part of the Pool. ${ }^{109}$ The issue was whether it would be appropriate to hold a defendant liable for a new tort of statutory breach, as distinct from claims of negligence, or whether the statutory breach should be subsumed within the law of negligence. ${ }^{110}$ If the former alternative were selected, the Court would be endorsing a form of absolute liability. The Court held as follows:

\begin{abstract}
One of the main reasons for shifting a loss to a defendant is that he has been at fault, that he has done some act which should be discouraged. There is then good reason for taking money from the defendant as well as a reason for giving it to the plaintiff who has suffered from the fault of the defendant. But there seems little in the way of defensible policy for holding a defendant who breached a statutory duty unwittingly to be negligent and obligated to pay even though not at fault. The legislature has imposed a penalty on a strictly admonitory basis and there seems little justification to add civil liability when such liability would tend to produce liability without fault. The legislature has determined the proper penalty for the defendant's wrong but if tort admonition of liability without fault is to be added, the financial consequences will be measured, not by the amount of the penalty, but by the amount of money which is required to compensate the plaintiff. Minimum fault may subject the defendant to heavy liability. Inconsequential violations should not subject the violator to any civil liability at all but should be left to the criminal courts for enforcement of a fine.
\end{abstract}

In this case the Board contends that the duty imposed by the Act is absolute, that is to say, the Pool is liable, even in absence of fault, and all that is requisite to prove a breach of duty is to show that the requirements of the statute have not, in fact, been complied with; it is not necessary to show how the failure to comply arose or that the Pool was guilty of any failure to take reasonable care to comply.

\begin{abstract}
The tendency of the law of recent times is to ameliorate the rigors of absolute rules and absolute duty in the sense indicated, as contrary to natural justice. "Sound policy lets losses lie where they fall, except where a special reason can be shown for interference”: Holmes, The Common Law, at p. 50. In the case at bar the evidence is that substantially all of the grain entering the terminal of the Pool at Thunder Bay came from agents of the Board. The imposition of heavy financial burden as in this case without fault on the part of the Pool does not incline one to interfere. It is better that the loss lies where it falls, upon the Board. ${ }^{111}$
\end{abstract}

This is not meant to deny that there is language in Saskatchewan Wheat Pool that suggests a difference between statutory breach and liability for negligence. Such language is clearly present. ${ }^{112}$ However, this distinction is not made in a vacuum. Rather, it is made in the context of a claim by a plaintiff of civil responsibility lying on the defendant without any fault on the defendant's part, which the Supreme Court of Canada says is to be avoided. I agree.

However, in the case of the statutory duty of care, there is no allegation of a lack of fault on the part of the defendant. In fact, the plaintiff must specifically show a lack of care by the defendant. Therefore, there can be no liability for breach of the statute without fault on the part of the defendant. In short, though Saskatchewan Wheat Pool does draw a meaningful 
distinction, the implication that this distinction is relevant to the decision in $B C E$ is misplaced.

Fourth, as mentioned above, the meaning to be ascribed to "an independent foundation for claims"113 may be very contextual. The duty of care was the second remedy referred to by the Court in BCE. ${ }^{114}$ The third was the oppression remedy. At one level, it is obvious that the oppression remedy is designed to alter the previous common law position. At common law, it was very difficult to prove oppression and the potential remedies were exceptionally narrow. ${ }^{115}$ The statutory oppression remedy was designed to be "an independent foundation for claims," in that it is now focused on what is "just and equitable" as between the parties, ${ }^{116}$ independent of the strictures of the prior common law. Therefore, the "no independent foundation" statement may simply serve to highlight the distinction between the duty of care, on the one hand, and the oppression remedy, on the other.

\section{g. Conclusion}

In concluding this point, in view of the dictates of s. 122(3) and the limitations of s. 124(5) in attempting to alleviate these concerns, the expanded duty of care is inappropriate. The statutorily-mandated ignorance of contractual provisions that might otherwise be used to protect the interests of directors makes a good deal of sense in the case of a suit by the corporation against its own director. The same ignorance is much harder to defend in the case of third parties, particularly where the limitation of liability is freely negotiated in a contract between the third party creditor, on the one hand, and the corporation and/or the person who owes the duty of care, on the other. Furthermore, even though there is some language in $B C E$ that might appear to some to assuage these concerns, this assertion cannot stand up to close scrutiny. Therefore, the narrower view of the duty of care should be reconsidered.

\section{Different Sections Within the SAme StatuTe}

Under this heading, the argument is illustrative, not exhaustive. In other words, although I will refer to the redundancy and incoherence of s. 119 based on the expanded scope of the duty of care in Peoples, this is not meant to provide a full catalogue of potential inconsistencies between s. 122(1)(b) and other provisions of the CBCA. Rather, the point is sufficiently made if the interpretation in Peoples leads to a form of absurdity with any other provision. In this case, it will be argued that such an absurdity exists.

a. What Are Absurdity and Tautology?

Like the categories of negligence at common law, the categories of absurdity in statutory interpretation are not closed. ${ }^{117}$ Sullivan explains one recognized form of absurdity as follows:

\footnotetext{
$113 \quad$ BCE, supra note 7 at para. 44.

114 Ibid. at para. 43 (noting that the first remedy was a derivative action).

115 Christopher C. Nicholls, Corporate Law (Toronto: Emond-Montgomery, 2005) at 419-22.

$116 \quad$ BCE, supra note 7 at para. 58.

$117 \quad$ Sullivan, supra note 45 at 309.
} 
Purpose is defeated. Statutory interpretation is founded on the assumption that legislatures are rational and competent agents. They enact legislation to achieve a particular mix of purposes, and each provision in the Act or regulation contributes to realizing those purposes in a specific way. An interpretation that would tend to frustrate legislate purpose or thwart the legislative scheme is likely to be labelled absurd. ${ }^{118}$

Sullivan also points out that every word used by the legislature to express its intention in a statute is presumed to have some meaning. She calls this the "presumption against tautology." With respect to this presumption, she writes: "It is presumed that the legislature avoids superfluous or meaningless words, that it does not pointlessly repeat itself or speak in vain. Every word in a statute is presumed to make sense and to have a specific role to play in advancing the legislative purpose."119

\section{b. What Is the Legislative Purpose of Section 119 of the CBCA?}

As we can see, therefore, legislative purpose is an essential element to this analysis. What, then, is the legislative purpose of the section? For current needs, this is established by the decision in Crabtree. ${ }^{120}$ In establishing the purpose of the section, the Court relied on two pieces of academic writing. ${ }^{121}$ The first, from Professor Marie-Louis Beaulieu, stated:

And why would this penalty involve requiring them to pay the employees rather than the company's other creditors?

It will perhaps be said that such creditors deserve special consideration by the law: that is very true; and it is more logical to say that Parliament wished to protect the worker and nothing more, to give him a remedial action, a guarantee of payment, in view of his often difficult situation. As he has nothing to do with administration, he should not suffer the consequences of a disaster; he does not speculate, he will be paid for what his work is worth, whatever the company's profits. ${ }^{122}$

Professors Frank Iacobucci (as he then was), ${ }^{123}$ Marilyn L. Pilkington, and J. Robert Prichard came to a similar conclusion:

This liability is an intrusion on the principle of corporate personality and limited liability, but it can be justified on the grounds that directors who authorize or acquiesce in the continued employment of workers when the corporation is not in a position to pay them should not be able to shift the loss onto the shoulders of the employees. Other creditors who supply goods and services to a failing corporation are not entitled to this kind of preference, but neither are they as dependent on the corporation as employees, nor as vulnerable. $^{124}$

Ibid.

Ibid. at 210.

Barrette v. Crabtree Estate, [1993] 1 S.C.R. 1027 [Crabtree].

Ibid. at 1042-43.

Ibid. at 1042 .

Interestingly, Iacobucci J. did sit on the hearing of the Peoples case at the level of the Supreme Court of Canada. However, he took no part in the judgment. 
This establishes that the legislative purpose of s. 119 was and is the protection of a particularly vulnerable class of creditor, that is, employees. Other creditors do not need as much protection as do employees. Therefore, s. 119, or, more precisely, its predecessor, was inserted into the $C B C A$ as one means of providing this protection. Below, I will demonstrate that, in two different ways, the expansive view of the duty of care robs s. 119 of its intended remedial effect.

\section{c. The Similarity Between Section 123(4) and the Duty of Care}

The basic argument is as follows: absurdity exists where the clear purpose of s. 119 of the $C B C A$ is frustrated by the interpretation of s. 122(1)(b). The purpose of s. 119 is to make it easier for vulnerable creditors, that is, unpaid employees, to sue directors for up to six months worth of wages. Yet, if the expansive view of the duty of care is correct, then here are the relevant words of s. 123(4): “[a] director is not liable under section 118 or 119 ... if the director exercised the care, diligence and skill that a reasonably prudent person would have exercised in comparable circumstances."125

Placed in opposite terms, no reliance may be placed on s. 119 unless a director has not exercised the care, diligence, and skill that a reasonably prudent person would have exercised in comparable circumstances. This is the exact same test necessary to prove the violation of the duty of care. Therefore, s. 119 is only accessible where the duty of care has already been violated. To put this into the expanded view of the duty of care of the Supreme Court in Peoples, the unpaid employees are creditors of the company. There is a violation of the duty of care. Under the expansive view of the duty of care, the creditors have a right to sue for the violation of the duty. Yet, if this is truly the case, then s. 119 is redundant, because all suits that could otherwise be brought under s. 119 could equally be brought by the creditors under the Peoples expanded version of the duty of care. This interpretation would run counter to the presumption against tautology referred to by Sullivan. Secondly, the other prerequisites contained in the wording of s. 119 make it harder to use s. 119. It is to this issue that attention now turns.

\section{d. The Other Pre-Requisites to the Use of Section 119}

Sections 119(2)(a)-(c) put barriers in the way of recompense under s. 119. These barriers are not present in the case of the duty of care. For example, to prove a breach of the duty of care, the plaintiff need not show any of the following:

(i) the corporation has been sued for a debt within six months after it has become due;

(ii) execution on the debt has been returned unsatisfied in whole or in part;

(iii) the corporation has commenced liquidation and dissolution proceedings;

(iv) the corporation has been dissolved; 
(v) a claim for the debt has been proved within six months after the earlier of the date of (iii) or (iv);

(vi) the corporation has made an assignment into bankruptcy;

(vii) a bankruptcy order has been made against the corporation under the Bankruptcy and Insolvency Act; or

(viii) a claim for the debt has been proved within six months after the date of (vi) or (vii).

In addition, recovery is limited to six months worth of wages and damages for unjust dismissal are not covered. ${ }^{126}$ The same is true of payment in lieu of notice. ${ }^{127}$ Admittedly, not all of these prerequisites need be proven in a single case. But the application of even one of them is sufficient to make an allegation of a breach of the duty of care more attractive than the use of s. 119. This, in itself, turns the legislative purpose of s. 119 on its head. Instead of offering an employee better protection than the ordinary creditor (the purpose of the section, according to Professor Beaulieu, on the one hand, and Professors Iacobucci, Pilkington, and Pritchard, on the other, as well as the Court in Crabtree), the section actually puts barriers in the way of its use so that the ordinary creditor is in a better position than an employee. At best, the expansive interpretation of the duty of care offered by Peoples renders s. 119 redundant. This violates the presumption against tautology. Or, it means that the wording of the section actually runs counter to its legislative purpose. This is absurd. In either instance, such an interpretation is to be avoided.

\section{Does This Mean That Directors CAN NeVER Be Liable?}

On the approach offered herein, directors may be liable to creditors in appropriate circumstances, though not through the route of the statutory duty of care. Directors may be held liable through other means. For example, as the Court points out in Peoples, the oppression remedy is available to deal with certain types of inappropriate director conduct, including losses caused to creditors. ${ }^{128}$ This alone proves that even if the duty of care is interpreted narrowly, it does not completely insulate directors from liability. The statute itself already provides other mechanisms.

Meanwhile, the common law is not without something to say on this point. The law of director liability for torts of the corporation is relevant to this discussion. This area of law has been in a state of evolution for the last ten years. Several of the pertinent cases are

$126 \quad$ Mesheau v. Campbell (1982), 39 O.R. (2d) 702 (C.A.).

127 Crabtree, supra note 120 at 1048-49.

128 Peoples, supra note 1 at paras. 48-51. This is not to say that I agree with the assertion by the Court that this is at least one justification for not extending the fiduciary duty to creditors (at para. 53). But, this should settle worries that the proposals made in this article are such that, if accepted by the Court, would lead to virtual immunity for director conduct. Nothing could be further from the truth. The provisions of the statute itself ensure this. Therefore, the need to expand the duty of care is less compelling than it might be if, for example, the duty of care were legitimately seen as the only mechanism through which directors could be held liable for misconduct against creditors. 
inconsistent with each other, ${ }^{129}$ both with respect to the test to be used in these cases, and its application to any particular set of facts. ${ }^{130}$ However, two things are clear. First, these cases are highly fact dependent. ${ }^{131}$ This means that a court, in preparing its judgment, can consider

See ScotiaMcLeod Inc. v. Peoples Jewellers Ltd. (1995), 26 O.R. (3d) 481 (C.A.) [ScotiaMcLeod]; Mentmore Manufacturing Co. v. National Merchandising Manufacturing Co. (1978), 89 D.L.R. (3d) 195 (F.C.A.) [Mentmore]; ADGA Systems International Ltd. v. Valcom Ltd. (1999), 43 O.R. (3d) 101 (C.A.), leave to appeal to S.C.C. refused, [1999] S.C.C.A. No. 124 (QL) [ADGA]; Pryce v. Vuckovich (2000), 144 O.A.C. 256 [Pryce], leave to appeal to S.C.C. refused, [2000] S.C.C.A. No. 559 (QL). In ScotiaMcLeod, ibid. at 491, the test was described as follows:

Absent allegations which fit within the categories described above [fraud, deceit, dishonesty or want of authority on the part of employees or officers], officers or employees of limited companies are protected from personal liability unless it can be shown that their actions are themselves tortious or exhibit a separate identity or interest from that of the company so as to make the act or conduct complained of their own.

This would seem to establish quite a high standard to hold directors liable for torts occurring in the corporate context. In ADGA, ibid. at 107, the Court held: "The consistent line of authority in Canada holds simply that, in all events, officers, directors and employees of corporations are responsible for their tortious conduct even though that conduct was directed in a bona fide manner to the best interests of the company, always subject to the Said v. Butt exception.” Meanwhile, paradoxically, the ScotiaMcLeod test was recognized and affirmed (at 112). In Mentmore, ibid. at 204-205, the distinction is between a "wilful and knowing pursuit" of tortious conduct, as opposed to the "ordinary course of [the director's] relationship" with the corporation. In other words, there are three different cases, and each has a different test.

131 Each comes from a very different context. In ScotiaMcLeod, ibid., the issue was one involving the issuance of securities. Arguably, these did not have the properties represented by the corporation. There were a number of members of the board who were not involved in any meaningful way with the representations at issue. There were no specific allegations of wrongdoing against the directors. The allegations made against the corporation were simply repeated against the directors, whether they were involved with the transaction or not. These passive directors argued that the claim against them should be struck out at the pretrial stage. The Court agreed. The Court refused to strike out the claim against the directors who were alleged to have actually made the representations.

If it were too easy to hold the directors liable in those circumstances, at least two interrelated policy consequences would follow. Both would, in my view, be unfavourable. First, the directors would in essence become insurers of the torts for which the corporation itself is meant to be responsible. Second, such liability could be viewed as detrimental to the concept of the separate legal personality of the corporation. There is an argument that liability on more than one person would not necessarily threaten separate legal personality. After all, vicarious liability puts responsibility on the corporation for the wrongs of another. But, in a case where the liability of the corporation leads virtually inexorably to liability for the directors as it would have had to in order for the passive directors to be liable under these circumstances, this is very problematic.

In $A D G A$, ibid., on the other hand, the executives of Valcom caused the employees of ADGA to breach their fiduciary obligations to their then-current employer ADGA, and come to work for Valcom, so that Valcom could compete with ADGA with respect to a contract in which both were interested. ADGA lost the contract to Valcom and sued Valcom and the director and executives involved in the recruitment of ADGA employees. The Court upheld liability.

There have been many explanations of the result in this case. For one example, see Bruce Welling, "Individual Liability for Corporate Acts: The Defence of Hobson's Choice” (2000) 12 Supreme Court Law Review (2d) 55. However, my own view of the case is a little different than that offered by Professor Welling. One could justify the result in the case on the ground that the "poaching" of the employees of one's competition is not an acceptable business practice. Therefore, the law will not countenance it. Put another way, the fiduciary obligation of a director does not entitle, or require, the director to undertake a breach of basic legal standards, such as respect for the law. The law requires that no person should deliberately entice a second person to breach the second person's obligation to a third party. The breach of this standard cannot be conducted without consequence. The position as a director does not alter this basic rule. Therefore, the executive and the director in the case could and should be held liable in these circumstances.

Finally, in Mentmore, ibid., there was an allegation of patent infringement. This case is quite explicit 
all of the relevant factors, such as the contractual provisions between the corporation and the creditor at issue. While this may be a little uncertain, the flexibility will ensure that a court can examine the overall relationship between the parties, so as to determine whether it is appropriate to hold any director liable. This would include all policy considerations. Interestingly, in Pryce, the Court held:

The appellant is asking us to remit our position relating to tortious acts by employees of corporation as set out in ScotiaMcLeod v. Peoples Jewellers 26 O.R. (3d) 481 and ADGA Systems International v. Valcom (1999) 43 O.R. (3d) 101. We decline to do so and repeat which we said in ADGA that the policy considerations which in these decisions, if they are to be considered should be done by the Supreme Court of Canada. ${ }^{132}$

Therefore, the Ontario Court of Appeal is unwilling to consider policy at all. Despite this assertion, there can be little doubt that there is an element of policy at play in this area of law. As Le Dain J. of the Federal Court of Appeal (as he then was) put it in Mentmore:

\begin{abstract}
What is involved here is a very difficult question of policy. On the one hand, there is the principle that an incorporated company is separate and distinct in law from its shareholders, directors and officers, and it is in the interests of the commercial purposes served by the incorporated enterprise that they should as a general rule enjoy the benefit of the limited liability afforded by incorporation. On the other hand, there is the principle that everyone should answer for his tortious acts. The balancing of these two considerations in the field of patent infringement is particularly difficult. ${ }^{133}$
\end{abstract}

Therefore, contrary to the assertion of the Court in Pryce, not only is policy in play, there are conflicting policy goals at issue. ${ }^{134}$ The refusal to acknowledge these considerations does

about the policy dilemma to be faced in these cases. Where the director is acting in the ordinary course of his relationship to the corporation, personal liability should generally not be found. On the other hand, where the director "directs or procures" a deliberate or willful infringement, liability should ensue. On which side of this line the director's conduct falls is highly dependent on the facts of the case.

Pryce, supra note 129 at para. 1 .

Mentmore, supra note 129 at 202.

For one example of the conflicting policy goals in this area of the law, one need look no further than the "neighbour" principle that runs through the law of torts, and in particular, the law of negligence. As La Forest J. makes clear in London Drugs, supra note 84, deterrence is one of the major policy goals of vicarious liability. I believe that one can go further and say that deterring risky behaviour that may do damage to someone else is a policy goal of the law of negligence generally. However, the separate legal personality of the corporation is specifically designed to encourage risk taking by people engaged in business by not forcing them to absorb all the economic costs should that risk crystallize into a loss. In other words, corporate law takes the risk of loss away from the shareholders. However, the risk does not simply disappear. Its removal from shareholders places the risk of loss on other stakeholders, such as creditors: see J. Anthony VanDuzer, The Law of Partnerships and Corporations, 2d ed. (Toronto: Irwin Law, 2003) at 95-96.

Therefore, in my view, one of the quintessential principles of tort law (the "neighbour" principle) fits uncomfortably with one of the equally quintessential principles of modern Canadian corporate law (limited liability). This tension needs to be resolved on a case by case basis. This explains why the case law is so fact-dependent. I am not ignoring the fact that directors are subject to the "neighbour" principle (as is everyone else). Rather, the two must coexist in the context of directors duties. In this article, I simply accept that there is a countervailing policy expectation (limited liability) that suggests that neither one of these principles must necessarily give way to the other in all circumstances. The Supreme Court in Peoples also makes it clear that a corporation must behave as a "good corporate citizen": see BCE supra note 7 at para. 81 . The "good corporate citizen" is another policy that must be added to the mix. 
not make them disappear. It simply makes the judicial process, and the reasoning that drives it, less transparent. With less transparency, it is harder to build public confidence. By taking a narrower view of the duty of care, the law of torts can be used to balance these policy concerns. Depending on the factual matrix at issue in a given case, such policy balancing may not be possible under the duty of care. To take but one example that has already been discussed, the contractual provisions in force between the parties cannot be considered, pursuant to s. 122(3). Freedom of contract between the parties is an important consideration. It can be considered under the common law. However, consideration of this important element is off limits under the statutory duty of care.

\section{WHAT IS NEXT?}

Given that this issue was created by the Supreme Court of Canada's judgment, there are two potential answers. The Court itself could choose to fix this particular issue with a subsequent decision. However, this is unlikely in the near future, given that the Court did not do so in BCE. As well, the doctrine of stare decisis might be thought to apply. After all, in Peoples itself the Court held that there was not a breach of the duty of care by the defendants. In such a case, it was not important whether the duty of care is owed or not. The result the Court reached was not dependent on the scope of the beneficiary to whom the duty was owed. It was dependent on the fact that the Wise brothers did not violate the statutory duty of care to anyone. This is admittedly a narrow interpretation of the holding of the Court. But it is a plausible one on the facts presented by the Court in its judgment. The same is true of the decision in BCE. In fact, the Court said specifically that the duty of care "is not at issue in these proceedings as this is not a claim against the directors of the corporation for failing to meet their duty of care.”135

If this is acceptable then the doctrine of stare decisis does not apply at all because a case is only binding for that which is actually required to allow the Court to resolve the issue before it. Thus, the first solution would be for the Court to say that, in fact, its judgment in Peoples was not intended to be so broad as to grant access to the duty of care to all creditors in all circumstances. However, in my view, this is unlikely considering the length of the Supreme Court's discussion of the duty of care. Also, if the Court had wished to have the discussion be obiter dicta, it could have been much more explicit in so doing. Since it did not do this, this is unlikely to be utilized as a solution.

On a related point, the Supreme Court of Canada could use the legislative change in Ontario as a catalyst for a reconsideration of its earlier decision. In other words, the Court could view the idea of uniformity in corporate law as an important value that the Court should seek to foster. If so, the legislative changes in Ontario may mean that there is reason to re-examine the wisdom underlying the Peoples ruling. However, in my view, this is also unlikely. The judgment in Peoples is only four years old. BCE, which, in general, reaffirms Peoples is even more recent. A recent legislative change in the area, even in a Canadian

Balancing these principles will not be easy. But, as explained further below, just because something will prove difficult is not a reason to shy away from it. In fact, the difficulty may be the very reason that it must be done. 
jurisdiction as commercially important as Ontario, is probably not sufficient by itself to alter the Court's view on this important issue.

Finally, the Court could use a non-Quebec case to reconsider its position on this issue. Even assuming that the discussion of the duty of care is not obiter dictum, the underlying premise of the judgment is based on Quebec law. If the Court wanted to alter its position, it could do so in a case from outside Quebec because the legal basis for a decision could be different. ${ }^{136}$ All of these possibilities rely on the Supreme Court's desire to actually change its position on this issue. This is virtually impossible to predict in advance.

The other option is legislative change. Clearly, the Peoples case was the impetus for legislative change in Ontario. There is nothing to prevent the other provinces and territories from following suit. In fact, the change in Ontario is an additional impetus for those provinces and territories to alter their legislative schemes. With each jurisdiction that makes the alteration, the push toward harmonization becomes stronger. But, getting at least 12 other jurisdictions to make this change to improve harmonization is, once again, difficult to predict in advance.

\section{ConClusion}

In the end, the result with respect to the duty of care, as explained by the Supreme Court in Peoples, is defensible. Nonetheless, I believe that the approach in the amended Ontario legislation is better than the broader approach offered by the Supreme Court of Canada. First, I disagree with Major and Deschamps JJ. that the wider view of the duty of care is "obvious." Even experts in the area of corporate law had not taken such a view prior to Peoples. Second, the Court's reliance on the Civil Code undermines the analysis. Third, a narrower interpretation of the duty of care is more consistent with norms of Canadian statutory interpretation. This includes the relationship between: (i) two paragraphs of the same subsection, and (ii) two subsections of the same section; (iii) two sections of the same statute. All of these are relevant to the expanded group of beneficiaries to whom the statutory duty of care is said to apply, according to the Court in Peoples. Fourth, a narrower group of beneficiaries for the statutory duty of care does not create director immunity because the common law of torts can fill the void and ensure that all relevant policy concerns are addressed, which the statutory duty of care cannot. Finally, both the judicial and legislative branches have the opportunity to remedy this situation. However, there are difficulties with each of these. Nonetheless, I end with this thought: despite any difficulties, if the analysis is sound, I believe that the need for change is made out. If the need for change is established, then the difficulties should not be allowed to deter improvement. 